\title{
THE DEVELOPMENT OF PUBLIC RELATIONS AND PROTOCOL TEACHING MATERIAL BASED ON THE 2013 CURRICULUM IN VOCATIONAL SCHOOL
}

Andre N. Rahmanto

Office Administration Education Study Program, Sebelas Maret University of Surakarta andreyuda@yahoo.com

Arif Wahyu Wirawan

Office Administration Education Study Program, Sebelas Maret University of Surakarta id.arifwahyu@gmail.com

\begin{abstract}
This research aimed to describe the development of public relations and protocol office administration teaching material based on the 2013 curriculum in Vocational School (thereafter called SMK). This study was a Research \& Development ( $R \& D)$ using Borg \& Gall's model. This research involved Public Vocational School with Office Administration Specialty in Ex-Surakarta Residency area. Technique of collecting data used was interview with informants related to Office Administration teaching material. Meanwhile for the trial, technique of collecting data used was questionnaire survey distributed to teachers and students. The effectiveness of data collection was tested using test. Technique of analyzing data used was mix method, the combination of qualitative and quantitative methods. The result of analysis using 2-way anava obtained $F_{\text {statistic }}$ value of 0.829 in Vocational School with probability (sig.) value of 0.438. F test results are seen in the anova table in the sig column. Experiment group had an improvement of learning outcome better than the control one with the mean increase of 4.5 while control group had mean score of 2.3. Thus, it could be concluded that public relations and protocol teaching material based on the 2013 curriculum was feasible to use in Vocational School (SMK).
\end{abstract}

Keywords: development, public relations and protocol, teaching material 


\section{INTRODUCTION}

Lessons learned in Vocational Middle School (Sekolah Menengah Kejuruan/SMK) in Business and Management still use teaching materials that are limited to conceptual mastery. Most of the lessons only rely on theories that are not equipped with workoriented job sheets. Yet SMK is a type of vocational education that should be oriented to the mastery of practice so that graduates are really ready for work. Therefore, in the 2013 curriculum for SMK level in Business and Management, productive training hours of learning are reproduced more than the previous curriculum.

However, in fact, some of the main training subjects tested in the Competency Test are (1) handling incoming and outgoing mail, (2) filing, (3) handling the phone, (4) preparing a small cash book, (6) and (7) the manufacture of meeting minutes is also not yet available complete test materials and does not meet the minimum standards expected in the workplace. As a result of the non-fulfillment of minimum standards and incomplete teaching materials, students of SMK are not fully ready to deploy field work practices in the business world and industry and in turn the value of less maximal work practices.

Hariyanto (2012, p. 99) explains, an inexperienced teacher generally requires more detailed planning than an experienced teacher. The RPP component consists of: (a) subject identity columns, (b) competency standards, (c) basic competencies, (d) indicators of competency achievement, (e) learning objectives, (f) teaching materials (main material) (g) material/competence prerequisite, (h) time allocation, (i) learning method, (j) learning activity, (k) assessment and (l) learning resources.

The 2013 curriculum or CharacterBased Education is a new curriculum released by RI's Education and Culture Ministry to replace Education Unit Level Curriculum. The 2013 curriculum is the one emphasizing on understanding, skill, and character education, in which the students are required to understand the material, to be active in discussion and presentation and to have high decorum and discipline. The 2013 curriculum aims to prepare Indonesian human beings to have life ability as the faithful, productive, creative, innovative, and affective individuals and citizens that can contribute to living within society, nation, state, and world civilization (Menteri Pendidikan dan Kebudayaan Republik Indonesia, 2013).

In the implementation of learning process, teacher requires the availability of learning set, teaching material, and scenario. Learning set can be student book, student worksheet, Learning Implementation Plan (RPP), assignment book, and etc. Teaching material can be visual aids, modules, media, and etc. Because so many components should be fulfilled in the learning process, a teacher should understand those components piecemeal, particularly the teaching material becoming the main source of student activeness in independent learning.

Vocational School is a program education with purpose preparation of graduates who are not in to higher education to be better prepared enter the world of work (Suyanto, 2009 , p. 5). Meaning estuaries graduate high school Vocational (SMK) on the constraints on: (1) Working in a vocational field that is appropriate to disciplines that study at school, (2) Continuing education to the level of education which is higher like college, and (3) Entrepreneurship .

Considering the result of field survey particularly for education unit in Business and Management major of Vocational Middle Schools (SMK) in Solo Area including SMK Negeri 1 Surakarta, SMK Negeri 3 Surakarta, SMK Kristen 1 Surakarta, SMK Negeri 1 Karanganyar, and SMK Wikarya Karanganyar, it can be found that teachers of productive specialties still lack of practical teaching material to support theoretical material. Teachers rely only on text book provided by government in which not all students have it. The lack of teaching material can also be seen during Student Competency Competition (thereafter called LKS), in which no job sheet is available completely. It results in the students' scoring still below the mean score of Minimum Passing Criteria (KKM) specified by school (75).

Research on teaching materials in the field of Office Administration has not been done. Though the ability of this field is needed in almost all sectors ranging from education, health, law, land, business to government (public). For it is very important presumably 
Administrative Administrative offices prepare the output of graduates with a provision of competent qualifications and match the needs of the world of work. Readiness is one of them is through quality teaching materials.

Teaching material is a set of lesson material/substance (teaching materials) organized systematically, featuring the whole intact frame of competency to be mastered by the students in learning activity. Dick, Carey, \& Carey (2009, p. 230) states that:

"The Instructional Materials contain the content-either written, mediated, or facilitated by an instructor-that a student will use to achieve the objectives. This includes materials for the major objectives and the terminal objectives and any materials for enhancing memory and transfer. Instructional materials refer to any preexisting materials that are being incorporated, as well as to those materials that will be specifically developed for the objectives. The materials may also include information that the learners will use to guide their progress through the instruction".

Departemen Pendidikan Nasional (2008, p. 7) mentions that a teaching material should include at least: (1) learning instruction (student/teacher instruction), (2) competencies to be achieved, (3) content of learning material, (4) supporting information, (5) practices, (6) work instruction, may be in the form of job sheet (LK), (7) evaluation, and (8) response or feedback to the result of evaluation.

There are 3 types of teaching material suggested by Tinning, Macdonald, Wright, \& Hickey (2001, p. 257): printed material in the form of textbook, work book or exercise book, and job sheet completed with reading collections, (2) authentic and created teaching materials, the ones in the form of sources relevant to real life, in either printed or nonprinted forms; for example, the materials accessed by teachers and students themselves from magazine, newspaper, brochure, and internet source, and (3) non-printed teaching material such as audio materials, video or computer-based teaching material.

The findings of previous studies (Bradshaw, 2005; Pinto, McDonough, \& Boyd, 2011) show that text book, both printed and digital, remains to be main learning instrument and reference to the learners. The advantages of text teaching material is that it is relatively sustainable in long term to complete textbook equipped with worksheet to find out the achievement of competency and to facilitate the learning. From the explanation above, it can be concluded that textbook is the printed teaching material having many advantages over other teaching material types, so that the students can read and learn independently and can regulate tempo themselves.

The practical work-based teaching material used in this research is module. Module is one of printed teaching materials enabling the students to learn independently, and the module completed with job sheet is the one designed to facilitate learning practice. Teaching material is independent in nature meaning that it can be studied by the students independently, systematically and completely (Pannen \& Purwanto, 2001, p. 7).

Modules are a set of teaching materials that are presented systematically so that users can be with teachers / facilitators or without facilitators/teachers in learning. Thus, a module must be a teaching material as a substitute for the function of the teacher, if the teacher has a role to explain something then the module should be able to explain something with the language that is acceptable to learners in accordance with the level of knowledge and age.

In writing the instructional materials in particular the modules there are several steps that must be passed, namely: (a) analysis of SK and KD, (b) determine the title of the module, (c) Module code delivery, and d) writing module. (Departemen Pendidikan Nasional, 2008, pp. 18-19).

The learning conducted in Business Management major of Vocational School still uses teaching material limited to conceptual mastery. Most learning focuses on theory only without practical work-oriented job sheet. Meanwhile, SMK is a type of vocational education that should be practice mastery-oriented so that the graduates will be ready actually for job. Therefore, in the 2013 curriculum for Business and Management Major of SMK level, the time allotment for productive courses is increased more than that in previous curriculum. 
Nevertheless, in fact several main courses tested in Competency Test including (1) handling incoming and exiting mails, (2) archiving, (3) handling phone call, (4) organizing small cash book, (6) organizing the leader's service trip, and (7) preparing meeting minutes have not had the completed and test material yet and have not met the standard minimum expected in work realm. As a result of unfulfilled minimum standard and incomplete teaching material, the students of SMK have not been ready fully for on the job training in business realm and industrial world that in turn makes the on-the-job training score less maximal.

Teaching material of Public Relations course in SMK discusses a variety of public relations scopes that should be studied by Office Administration Specialty Program students in SMK. This Basic Competency contains, among others, public relations definition, public relations tasks, public relations officer requirement; appearance of a public relations officer, public relations activity public relations principle; public relations scope; public relations activity process; public relations function; public relations officer role; public relations objective; types of public relations and definitions of ethics, etiquette, and ethical code.

Considering the background of problem, the objective to be achieved in this research is to develop public relations and protocol office administration teaching material based on the 2013 curriculum in Vocational Middle Schools (SMK).

\section{METHOD}

This study was a Research and Development ( R \& D). It is called so because the end product expected from this research and development should meet the existing criteria: new product or product different from the ever existing one, ready to apply, and developed in the field; therefore, one of important research activities to be done is systematically field test. Such the product should be evaluated and accomplished in order to meet the specified criteria.

The product yielded in this research was Office Administration teaching material based on the 2013 curriculum in the form of Teaching Book with ISBN (Copyright). It is conducted because there has been no Office Administration teaching material based on the 2013 curriculum oriented to the teacher, student, and business world/industry needs so far. The teaching material existing today emphasizes on theory only and its availability is still very limited.

The research procedure conducted is corresponding to Gall, Borg, \& Gall's (2003, pp. 570-571) procedure, in this case including: (1) exploration, (2) draft model development, (3) model testing, and (4) teaching material product dissemination.

This research was taken place in Public Vocational Middle schools with Office Administration specialty in Surakarta City, Karanganyar, Boyolali, Sukoharjo, Klaten, Wonogiri, and Sragen Regencies, from January to September 2016.

The type of research data used was mix method (qualitative and quantitative data). Qualitative data was used particularly in exploration and model development stage, while quantitative data was used in model trial and model effectiveness test stages. Data source consisted of teacher and students of productive courses and related documents including curriculum, syllabus, RPP (learning implementation plan), teaching material, learning media, and other relevant documents.

Techniques of collecting data used were: in-depth interview with informants about any things related to Office Administration teaching material; passive observation on the learning activity of Office Administration using the existing teaching material; and document analysis, analyzing the document of Office Administration teaching material documents in Public Vocational Middle Schools in ex-Surakarta Residency, and relevant documents.

The validity of the data using triangulation techniques of source and triangulation method, source triangulation is by testing the validity of data from different sources, while triangulation method is to test data with different methods. Triangulation of sources is to compare the results of interviews from informants that one will check data with other informants, while triangulation method is to compare the results of interviews will be checked data with the results of observation and documents. 
Technique of analyzing data used in this research was mix method, the combination of qualitative and quantitative analyses. Qualitative data was analyzed using an interactive model of analysis (Miles \& Huberman, 1992, p. 20), while quantitative data was analyzed using statistic descriptive and variance test technique. The mix method was used in this research to obtain a complete analysis corresponding to the characteristics of data and the need according to the research procedure aforementioned.

\section{RESULT AND DISCUSSION}

\section{Data Normality Test}

Statistic test conducted to find out the normality of every cell was Shapiro wilk nonparametric statistic test because $n$ of each cell $<50$. The significance level was $5 \%$.

The result obtained is the probability value in the data of normally distributed difference has $\mathrm{p}$ value $>0.05$, while in the data of pretest, there are some cells not distributed normally. In the data of posttest, all cells are not distributed normally. Considering the result, the statistic test is used in the data of difference.

\section{Data Homogeneity Test}

Variance homogeneity test was conducted to test the similar variance of Office Administration learning value based on the groups of value existing in each cell. The statistic test used was levene test. This test is intended to test null hypothesis $\left(\mathrm{H}_{0}\right)$ stating that the variance of learning value viewed from those groups is homogeneous at significant level of $\alpha=0.05$, versus its counterpart hypothesis $\left(\mathrm{H}_{1}\right)$ stating that the variance of learning value viewed from the value groups is not homogeneous at the same significance level. The testing criterion used is that $\mathrm{H}_{0}$ is supported (homogeneous) if $\mathrm{p} \leq 0.05$. Otherwise, if $\mathrm{p}$ value $>0.05$, therefore $\mathrm{H}_{0}$ is not supported (not homogeneous).

The result obtained is probability (sig.) value of 0.000 . Probability value $<0.05$ meaning that $\mathrm{H}_{0}$ is not supported or the data of the four cells is heterogeneous. Considering the result of homogeneity test showing that the data is homogeneous, it can be concluded that advanced test used is adjusted alternative test, tamhane test.

Table 1. Result of Homogeneity Test

Levene's Test of Equality of Error Variances $^{\mathrm{a}}$

Dependent Variable: difference

\begin{tabular}{|l|l|l|l|}
\hline$F$ & df1 & df2 & Sig. \\
\hline 5.464 & 5 & 186 & .000 \\
\hline
\end{tabular}

Inter-group comparison is used to find out whether or not the groups have the same value. The groups to be compared are: (1) between schools, (2) between experiment and control groups, (3) between experiment and control treatments in individual schools.

\section{The comparison of Learning Outcome between SMK N Boyolali, SMKN 3 Surakarta, and SMKN 6 Surakarta}

The result of test using a 2-way anava obtains F statistic value of 32.313 in SMK with probability (sig.) value of 0.000 . Probability value is less than 0.05 meaning that there is a difference of learning outcome increase among the three schools. From table 4.1 , it can be seen that the mean score of increase is 1.61 for SMKN Boyolali, 3.17 for SMKN 3 Surakarta, and 5.37 for SMKN 6 Surakarta. The difference of increase among the SMKs is indicated with $p$ value $<0.05$ for all. From the statistical test, it could be concluded that the mean score of increases in SMKN 6 Surakarta > that in SMKN 3 Surakarta > that in SMKN Boyolali.

Those three SMKs have unequal pretest values in which SMKN Boyolali has the highest pretest value of 16.5 and SMKN 3 Surakarta has pretest value nearly equal to SMKN 3 Surakarta (10.7 and 10.6, respectively).

In SMKN Boyolali, the pretest value (16.5) is the highest one compared with that in others SMKNs. In posttest it increases slightly to 18.2 , it increases by 1.6 point only. In SMK N 3 Surakarta, the increase is slightly better compared that in SMKN Boyolali. The pretest value is 10.7 increasing to 13.9 , increasing by 3.2 points. And in SMK N 6 Surakarta there is a highest increase from pretest value of 10.6 to 16.0 , thereby increasing by 5.4 point. 
From this information, it can be concluded that SMKN Boyolali has highest pretest value but low increase. The increase of values in ascending order is as follows: SMKN Boyolali, SMKN 3 Surakarta and SMKN 6 Surakarta.

\section{The Comparison of Learning Outcome between Experiment and Control Groups}

The result of test using a 2-way anava shows F statistic value of 31.178 in the treatment with probability (sig.) value of 0.000 . The probability value $<0.05$, meaning that there is a difference of increase in learning outcome between experiment and control groups. From Table 4.9, it can be seen that experiment group has lower pretest than with the control group does. The experiment group has the mean pretest score of 11.8 and the mean posttest score of 16.3 , thereby increasing by 4.5 points. Meanwhile, the control one has pretest score of 13.4 and posttest score of 15.7, thereby increasing by 2.3 points. The result of statistic test shows that the mean difference of experiment-control is 2.146, $\mathrm{F}$ statistic value of 4.846 and $p$ value of 0.000 , meaning that the increase in learning outcome for experiment groups is higher than that for control group.

Table 2. Summary of Statistic test and the mean score of Learning Outcome Between Treatments

\begin{tabular}{lrrr}
\hline F-statistic & \multicolumn{3}{c}{31.178} \\
$\mathrm{P}$ & \multicolumn{3}{c}{0.000} \\
\hline Treatment & pretest & posttest & Difference \\
\hline Experiment & 11.8 & 16.3 & 4.5 \\
Control & 13.4 & 15.7 & 2.3 \\
\hline Exp. - control & & 2.146 & \\
t-statistic & & 4.846 & \\
$P$ & \multicolumn{3}{c}{0.000} \\
Conclusion & \multicolumn{3}{c}{ Exp > control } \\
\hline
\end{tabular}

From the Figure 1, it can be seen that the pretest score of experiment group is lower than that of control group, but the posttest score of experiment group is higher than that of control group. Considering the mean increase, it can be concluded that experiment has better result compared with the control group.

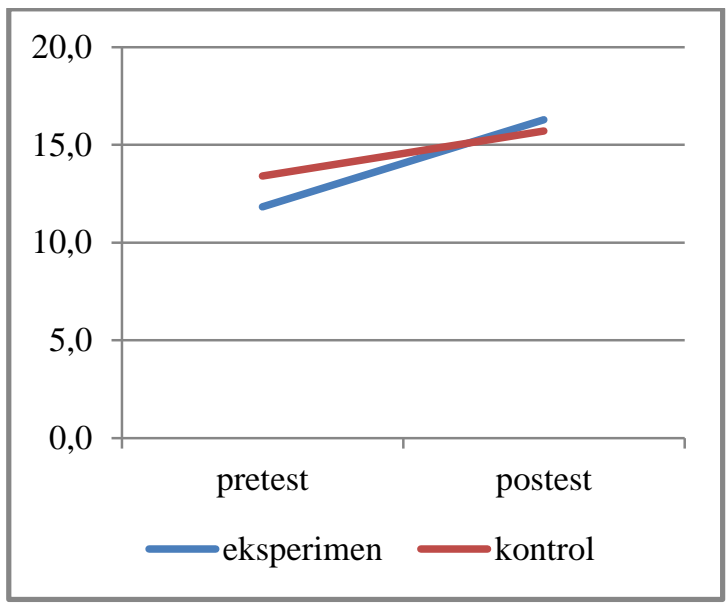

Figure 1. The comparison of Experiment and Control Groups

The Comparison of Learning Outcome in Experiment Group between SMK Boyolali, SMKN3 Surakarta, and SMK N 6 Surakarta

The result of test using a 2-way anava shows $F$ statistic value of 0.829 with probability (sig.) value of 0.438 . Probability value $>0.05$, meaning that there is no interaction between SMK and treatment.

From figure 2, it can be found that SMKN Boyolali has highest mean pretest score (15.6) compared with the other two SMKs and its posttest value is 18.6 , thereby increasing by 3.0 points. SMKN 3 Surakarta has mean pretest score of 9.8 and mean posttest score of 13.8, thereby increasing by 4.1 points. In SMKN 6 Surakarta, the mean posttest score is 10.2 and the posttest score is 6.3. From the statistic calculation, it can be concluded that the increase in SMK $\mathrm{N}$ Boyolali equals to SMKN 6 Surakarta. The result of statistical test shows that the increase in learning outcome is relatively equal in SMKN Boyolali and SMKN 3 Surakarta. However, the learning outcome in SMKN 6 Surakarta is higher than that in other SMKs.

From Figure 3, it can be seen that SMKN Boyolali has highest pretest and posttest scores but the increase is small. SMKN 3 has lowest mean score and after the treatment it is still the lowest one despite sufficiently high increase. SMKN 6 has the highest increase with the increase by 6.3 points. 


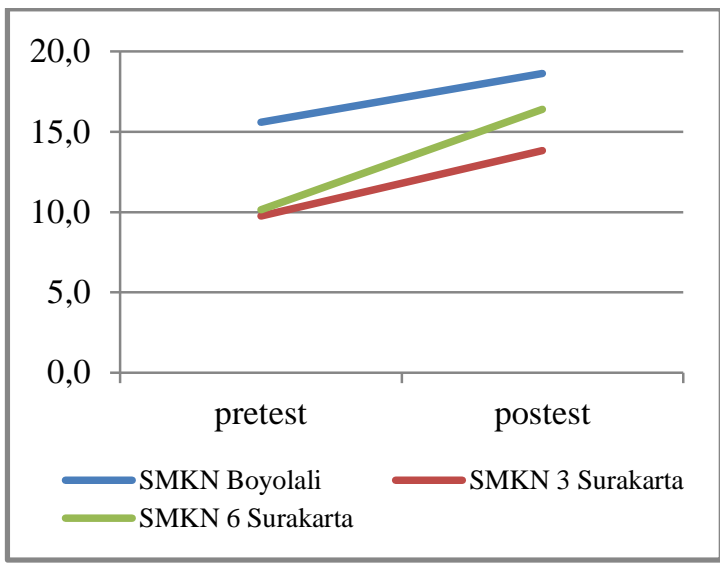

Figure 2. The comparison of Mean Learning Outcome in Experimental Group between SMKN Boyolali, SMKN

3 Surakarta, and SMKN 6 Surakarta

\section{Discussion}

Hynes, Costin, \& Birdthistle (2010, pp. 16-28) entitled Practice-based Learning in En-trepreneuship Education: A means of Connecting Knowledge Producers and Users. Research results show that practical-based learning brings learning into real-life in the classroom while bringing more flexible professional graduates and workable. Furthermore, creating a meaningful relationship between educational institutions and industry. This study proves that practical-based learning creates a good relationship between educational institutions and the industrial world.

Research Joyoatmojo (1997), entitled "Development of Written Teaching Materials to Improve Effectiveness of Learning". The study was conducted at Sebelas Maret University, the results of his research showed that there was a significant difference between the achievement of the students who obtained written materials developed based on the Dick and Carey model with the use of advance organizers compared with existing written materials. The teaching materials developed from Dick and Carey are better. This study proves that the teaching materials developed based on the Dick and Carey models are better than existing written teaching materials, thus the research contributes in the development of teaching materials to this research.

Untari, Suparlan, Ketut, \& Wahyu (2008, pp. 154-177) entitled "Development of Teaching Materials and Student Activity
Sheets of Civics with Deep Dialoque / Critical Thinking Approaches to Improve Dialogue and Critical Thinking Skills of High School Students in East Java". This study proves that teaching materials equipped with Student Activity Sheets are able to increase student participation in learning, so this research contributes that LKS / job sheet is effective in improving students' competence and supporting this research.

The result of Pujiati (2007, pp. 36-53) reserach, entitled "Development of Practicum Material Introduction to Accounting Accounting Students Accounting" shows that the development process of teaching materials Practicum Introduction to Accounting there is the influence of the use of textual material on the ability of Accounting Introduction Practicum in Class A students and Class B Department D-3 Accounting STIE Darmajaya Bandar Lampung.

Meanwhile, Ekawarna (2007, pp. 4247) research, entitled "Developing the subject of Cooperative Capital Learning Course to Improve Student Motivation and Student Result" indicates that the results stated that the teaching material script that has been developed can improve student learning outcomes.

\section{CONCLUSION}

Regardless the treatment, the highest mean score of increase occurs in SMKN 6 Surakarta with the mean score of 5.4, followed with SMKN 3 Surakarta with the mean score of 3.2 and followed with SMKN Boyolali with the smallest mean score of increase (1.6).

Experiment group has the mean increase of learning outcome better than control group does with the mean score of 4.5 in experiment group and 2.3 in control group.

Particularly, in experiment group, SMKN Boyolali has increase relatively equal to SMKN 3 Surakarta does. SMKN Boyolali has a mean increase score of 3.0 and SMKN 3 Surakarta has higher increase of 4.1. SMKN 6 Surakarta has higher learning outcome (6.3) than other two SMKs.

\section{REFERENCES}

Bradshaw, G. L. (2005). Multimedia textbooks and student learning. 
MERLOT Journal of Online Learning and Teaching, 1(2). Retrieved from http://jolt.merlot.org/documents/Vol1_N o2_bradshaw.pdf

Departemen Pendidikan Nasional. (2008). Panduan pengembangan bahan ajar. Jakarta: Ditjen Manajemen Dikdasmen.

Dick, W., Carey, L., \& Carey, J. O. (2009). The systematic design of instruction (7th ed.). Upper Saddler River, New Jersey: Pearson Education, Inc.

Ekawarna. (2007). Mengembangkan bahan ajar mata kuliah permodalan koperasi untuk meningkatkan motivasi dan hasil belajar mahasiswa. Makara, Sosial Humaniora, 11(1), 42-47. Retrieved from http://hubsasia.ui.ac.id/index.php/hubsas ia/article/viewFile/104/97

Gall, M. D., Gall, J. P., \& Borg, W. R. (2003). Educational research: an introduction (7th ed.). Boston: Allyn \& Bacon.

Hariyanto, V. L. (2012). Integrasi bahan ajar kewirausahaan bidang produktif bangunan. Jurnal Pendidikan Vokasi, 2(1). Retrieved from https://journal.uny.ac.id/index.php/jpv/ar ticle/view/1020

Hynes, B., Costin, Y., \& Birdthistle, N. (2010). Practice-based learning in entrepreneurship education: A means of connecting knowledge producers and users. Higher Education, Skills and Work-Based Learning, 1(1), 16-28. https://doi.org/10.1108/20423891111085 366

Joyoatmojo, S. (1997). Pengembangan bahan ajar tertulis untuk meningkatkan keefektifan pembelajaran. Disertasi. Program Pascasarjana IKIP Jakarta.

Menteri Pendidikan dan Kebudayaan Republik Indonesia. Peraturan Menteri Pendidikan Pendidikan dan Kebudayaan Republik Indonesia Nomor 70 Tahun
2013 tentang Kerangka Dasar dan Struktur Kurikulum Sekolah Menengah Kejuruan/Madrasah Aliyah Kejuruan (2013).

Miles, M. B., \& Huberman, A. M. (1992). Analisis data kualitatif: buku sumber tentang metode-metode baru. Jakarta: UI Press.

Pannen, P., \& Purwanto. (2001). Penulisan bahan ajar. Jakarta: Depdiknas.

Pinto, L. E., McDonough, G. P., \& Boyd, D. (2011). High school philosophy teachers' use of textbooks: critical thinking or teaching to the text? Journal of Curriculum and Instruction, 5(2). https://doi.org/10.3776/joci.2011.v5n2p4 5-78

Pujiati. (2007). Pengembangan bahan ajar praktikum pengantar akuntansi untuk mahasiswa Jurusan Akuntansi. Jurnal Ekonomi \& Pendidikan (Vol. 4).

Retrieved from https://journal.uny.ac.id/index.php/jep/ar ticle/view/609

Suyanto. (2009). Pembangunan pendidikan SMK. Jakarta: Departemen Pendidikan Nasional, Direktorat Jenderal Manajemen Pendidikan Dasar dan Menengah.

Tinning, R., Macdonald, D., Wright, J., \& Hickey, C. (2001). Becoming a physical education teacher: Contemporary and enduring issues. Frenchs Forest: Pearson Education Australia.

Untari, S., Suparlan, Ketut, \& Wahyu, N. (2008). Pengembangan bahan ajar dan LKS mata pelajaran PKn dengan pendekatan deep dialoque/ critical thingking untuk meningkatkan kemampuan berdialog dan berpikir kritis siswa SMA di Jawa Timur. Jurnal Penelitian Kependidikan, 18(1), 154177. 